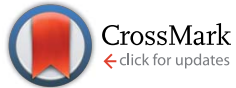

Cite this: RSC Adv., 2014, 4, 62793

Received 20th August 2014

Accepted 13th November 2014

DOI: $10.1039 / c 4 r a 08952 a$

www.rsc.org/advances

\section{Enhanced electrocatalytic performance of cobalt oxide nanocubes incorporating reduced graphene oxide as a modified platinum electrode for methanol oxidation $\dagger$}

Muhammad Mehmood Shahid, ${ }^{a}$ Alagarsamy Pandikumar, ${ }^{\text {a }}$ Amir Moradi Golsheikh, ${ }^{a}$ Nay Ming Huang ${ }^{\star a}$ and Hong Ngee Lim ${ }^{\star b c}$

Herein, we report a facile hydrothermal method for the preparation of cobalt oxide nanocubes incorporating reduced graphene oxide $\left(\mathrm{rGO}-\mathrm{CO}_{3} \mathrm{O}_{4}\right.$ nanocubes) for electrocatalytic oxidation of methanol. The synthesized $\mathrm{rGO}-\mathrm{CO}_{3} \mathrm{O}_{4}$ nanocubes were characterized using transmission electron microscopy (TEM), field emission scanning electron microscopy (FESEM), X-ray diffraction (XRD), and Raman techniques. The electrochemical behavior of an $\mathrm{rGO}-\mathrm{CO}_{3} \mathrm{O}_{4}$ nanocube modified electrode was studied using cyclic voltammetry (CV) and electrochemical impedance spectroscopy (EIS) techniques. The electrocatalytic performances of $\mathrm{rGO}-\mathrm{CO}_{3} \mathrm{O}_{4}$ nanocube-modified electrodes with different wt $\%$ of $\mathrm{GO}$ were investigated in relation to methanol oxidation in an alkaline medium. The $\mathrm{rGO}-\mathrm{Co}_{3} \mathrm{O}_{4}$ nanocube modified electrode showed enhanced current density due to oxidation of methanol when compared to the bare $\mathrm{Pt}, \mathrm{rGO}$, and $\mathrm{CO}_{3} \mathrm{O}_{4}$ nanocube modified electrodes. The optimal $\mathrm{GO}$ content for an $\mathrm{rGO}-\mathrm{CO}_{3} \mathrm{O}_{4}$ nanocube-modified electrode to achieve a high electrocatalytic oxidation of methanol was $2 \mathrm{wt} \%$, and it showed an anodic peak current density of $362 \mu \mathrm{A} \mathrm{cm}{ }^{-2}$.

\section{Introduction}

The constantly increasing energy demand due to the depletion of conventional fossil fuel reserves and the rapid growth of environmental issues have led to the search for alternative power sources. ${ }^{1,2}$ These include direct methanol fuel cells (DMFCs) as alternative green, environmentally friendly, and sustainable power sources that can directly convert the chemical energy of methanol into electrical energy. ${ }^{3,4}$ A polycrystalline Pt electrode is the most commonly used electrode material in DMFCs. However, its high cost, scarcity, low power density, and poor CO-poisoning tolerance significantly hinder its commercialization and practical application. ${ }^{5,6}$ In order to reach a high power density and low production cost for DMFCs, well-designed and fabricated high-performance electrocatalysts with controlled compositions and morphologies have emerged as suitable for realizing high device performance. ${ }^{5,6}$

\footnotetext{
${ }^{a}$ Low Dimensional Materials Research Centre, Department of Physics, Faculty of Science, University of Malaya, 50603 Kuala Lumpur, Malaysia. E-mail: huangnayming@um.edu.my; pandikumarinbox@gmail.com

${ }^{b}$ Department of Chemistry, Faculty of Science, Universiti Putra Malaysia, 43400 UPM Serdang, Selangor, Malaysia.E-mail: janet_limhn@science.upm.edu.my

${ }^{c}$ Functional Device Laboratory, Institute of Advanced Technology, Universiti Putra Malaysia, 43400 UPM Serdang, Selangor, Malaysia

$\dagger$ Electronic supplementary information (ESI) available: XRD analysis, electrochemical properties and electrocatalytic methanol oxidation. See DOI: 10.1039/c4ra08952a
}

In this area, carbon-based nanomaterials, including activated carbon, carbon nanotubes (SWCNT, DWCNT, MWCNT), GO, and rGO have enormous potential to boost the performance of DMFCs. ${ }^{3,7,8}$ Among these, graphene plays a crucial role in the fabrication of advanced composite/hybrid electrocatalysts for high performance DMFCs because of its unique physicochemical properties, including a high specific surface area, superior electronic conductivity, and excellent stability. ${ }^{8-13}$ Several attempts have been made to apply metal and metal oxide nanomaterials incorporating graphene modified electrodes in DMFC applications to attain a high power density. ${ }^{\mathbf{1 4 , 1 5}}$

Metal oxide incorporating graphene composites have gained tremendous attention because of their low-cost, facile synthesis, high electrocatalytic activity, and durability in DMFC applications., ${ }^{\mathbf{4 , 8 1 1 , 1 4 , 1 5}}$ Currently, cobalt oxide $\left(\mathrm{Co}_{3} \mathrm{O}_{4}\right)$ nanomaterials are more attractive due to their simple preparation method, diverse morphology, high catalytic activity, and applicability in electrocatalysis. ${ }^{16}$ Recently, $\mathrm{Co}_{3} \mathrm{O}_{4}$ nanomaterials combined with graphene have shown excellent electrocatalytic activities. Hence, these have been applied in the field of electrochemical energy conversion and storage. ${ }^{17}$ Xiao et al. reported the influence of the surface structure on the electrocatalytic activity of $\mathrm{Co}_{3} \mathrm{O}_{4}$ anchored graphene sheets toward an oxygen reduction reaction for a fuel cell application. $^{18}$ 
In the present investigation, cobalt oxide nanocubes incorporated reduced graphene oxide $\left(\mathrm{rGO}-\mathrm{Co}_{3} \mathrm{O}_{4}\right.$ nanocubes) were prepared using GO (simplified Hummer's method ${ }^{19}$ ) with Co(II) ions by a simple hydrothermal method and used for electrocatalytic methanol oxidation. The as-prepared $\mathrm{rGO}-\mathrm{Co}_{3} \mathrm{O}_{4}$ nanocubes were characterized using TEM, FESEM, XRD, and Raman techniques. The electrochemical behavior of $\mathrm{rGO}-\mathrm{Co}_{3} \mathrm{O}_{4}$ nanocubes modified electrode was investigated using the $\mathrm{CV}$ and EIS techniques with a $\left[\mathrm{Fe}_{3}(\mathrm{CN})_{6}\right]$ redox couple as an electrochemical probe. The electrocatalytic performance toward methanol oxidation was investigated in an alkaline medium for rGO- $\mathrm{Co}_{3} \mathrm{O}_{4}$ nanocubes modified electrodes with different wt $\%$ of GO content and the optimized GO content for high performance was found to be $2 \mathrm{wt} \%$, with a high peak current density of $362 \mu \mathrm{A} \mathrm{cm}^{-2}$ during a forward scan. The high electrochemical performance, low-cost, and ease of fabrication make these rGO$\mathrm{Co}_{3} \mathrm{O}_{4}$ nanocubes modified electrode a potential candidate for direct methanol fuel cell applications.

\section{Experimental methods}

\section{Materials}

Graphite flakes were purchased from Asbury Inc. (USA). Sulfuric acid $\left(\mathrm{H}_{2} \mathrm{SO}_{4}, 98 \%\right)$, potassium permanganate $\left(\mathrm{KMnO}_{4},>99 \%\right)$, hydrochloric acid $(\mathrm{HCl}, 35 \%)$, and ammonia solution $\left(\mathrm{NH}_{3}\right.$, $25 \%$ ) were purchased from $\mathrm{R} \& \mathrm{M}$ Chemicals. Cobalt acetate tetrahydrate $\left(\mathrm{Co}\left(\mathrm{CH}_{3} \mathrm{COO}\right)_{2} \cdot 4 \mathrm{H}_{2} \mathrm{O}\right)$ was purchased from Sigma Aldrich. Hydrogen peroxide $\left(\mathrm{H}_{2} \mathrm{O}_{2}, 35 \%\right)$ and methanol $\left(\mathrm{CH}_{3} \mathrm{OH}\right)$ were obtained from Systerm, Malaysia. Distilled water was used throughout the experimental work.

\section{Synthesis of $\mathrm{rGO}-\mathrm{Co}_{3} \mathrm{O}_{4}$ nanocubes}

In the typical process for the preparation of $\mathrm{rGO}-\mathrm{Co}_{3} \mathrm{O}_{4}$ nanocubes, the graphene oxide (GO) was prepared by using a simplified Hummer's method. ${ }^{19}$ A $12 \mathrm{~mL}$ of $\mathrm{Co}\left(\mathrm{CH}_{3} \mathrm{COO}\right)_{2} \cdot 4 \mathrm{H}_{2} \mathrm{O}$ (83 $\mathrm{mM})$ was mixed with different wt\% of GO $(1,2,4,8$, and $12 \mathrm{wt} \%$ ) and stirred for $2 \mathrm{~h}$ to obtain a homogeneous solution. After that, $15 \mathrm{~mL}$ of $6 \%$ ammonia was slowly added drop-wise into the above reaction mixture under vigorous stirring. Then, $75 \mathrm{~mL}$ of the reaction mixture was transferred to a $100 \mathrm{~mL}$ Teflonlined stainless steel autoclave and subjected to hydrothermal treatment at $180{ }^{\circ} \mathrm{C}$ for $12 \mathrm{~h}$. Finally, the obtained precipitate of rGO- $\mathrm{Co}_{3} \mathrm{O}_{4}$ nanocubes was washed five times with DI water and ethanol and dried in a hot air oven at $60{ }^{\circ} \mathrm{C}$. For comparison, $\mathrm{Co}_{3} \mathrm{O}_{4}$ and $\mathrm{rGO}$ were prepared using a similar method without using GO and $\left(\mathrm{Co}\left(\mathrm{CH}_{3} \mathrm{COO}\right)_{2} \cdot 4 \mathrm{H}_{2} \mathrm{O}\right)$, respectively.

\section{Preparation of modified electrode}

An $\mathrm{rGO}-\mathrm{Co}_{3} \mathrm{O}_{4}$ nanocubes modified electrode was fabricated by dispersing $1 \mathrm{mg}$ of the synthesized $\mathrm{rGO}-\mathrm{Co}_{3} \mathrm{O}_{4}$ nanocubes in $1 \mathrm{~mL}$ of deionized water and then sonicating it for $30 \mathrm{~min}$ to ensure a homogeneous dispersion. A $5 \mu \mathrm{L}$ of the colloidal rGO$\mathrm{Co}_{3} \mathrm{O}_{4}$ nanocubes solution was cast on a polycrystalline $\mathrm{Pt}$ electrode and then dried in a hot air oven at $65{ }^{\circ} \mathrm{C}$ for $1 \mathrm{~h}$. This $\mathrm{Pt} / \mathrm{rGO}-\mathrm{Co}_{3} \mathrm{O}_{4}$ nanocubes modified electrode was used for the electrocatalytic oxidation of methanol.

\section{Characterization techniques}

The size and shape of the $\mathrm{rGO}-\mathrm{Co}_{3} \mathrm{O}_{4}$ nanocubes were studied using a JEOL JEM-2100F high-resolution transmission electron microscope. The surface morphology and elemental composition were examined using a JEOL JSM-7600F field emission scanning electron microscope. Raman spectra were acquired from a Renishaw inVia 2000 system with a green laser emitting at $532 \mathrm{~nm}$. The crystalline nature and phase identification of the rGO- $\mathrm{Co}_{3} \mathrm{O}_{4}$ nanocubes were recorded using a Philips X'pert $\mathrm{X}$-ray diffractometer with copper $\mathrm{K} \alpha$ radiation $(\lambda=1.5418 \AA)$ at a scan rate of $0.02^{\circ} \mathrm{sec}^{-1}$. All the electrochemical measurements were carried out using a VersaSTAT-3 electrochemical analyzer (Princeton Applied Research, USA) with a conventional threeelectrode system under a nitrogen atmosphere at room temperature $\left(27{ }^{\circ} \mathrm{C}\right)$. The $\mathrm{rGO}-\mathrm{Co}_{3} \mathrm{O}_{4}$ nanocubes modified electrode was used as a working electrode, a platinum wire served as a counter electrode, and a $\mathrm{Ag} / \mathrm{AgCl}$ electrode was the reference electrode. The supporting electrolyte and target substrate were composed of $0.1 \mathrm{M} \mathrm{KOH}$ and $0.1 \mathrm{M} \mathrm{CH} \mathrm{CH}_{3} \mathrm{OH}$, respectively. All the potentials are quoted against the $\mathrm{Ag} / \mathrm{AgCl}$ electrode unless otherwise mentioned.

\section{Results and discussion}

\section{Formation of rGO- $\mathrm{Co}_{3} \mathrm{O}_{4}$ nanocubes}

Fig. 1 shows a schematic illustration of the formation of $\mathrm{Co}_{3} \mathrm{O}_{4}$ nanocubes incorporated rGO sheets fabricated using a hydrothermal method. In this typical synthetic process, a $\mathrm{Co}$ (II) precursor was added to the preformed GO solution, and the medium was changed to basic with the help of an $\mathrm{NH}_{3} \cdot \mathrm{H}_{2} \mathrm{O}$ solution. Upon the hydrothermal process, the $\mathrm{GO}-\mathrm{Co}(\mathrm{OH})_{2}$ transformed into rGO- $\mathrm{Co}_{3} \mathrm{O}_{4}$ nanocubes. The $\mathrm{Co}_{3} \mathrm{O}_{4}$ nanocubes were incorporated like spacers between the disorderedly stacked graphene sheets.

\section{Morphological studies of $\mathrm{rGO}-\mathrm{Co}_{3} \mathrm{O}_{4}$ nanocubes}

The FESEM images of the $\mathrm{rGO}-\mathrm{Co}_{3} \mathrm{O}_{4}$ nanocubes show that the $\mathrm{Co}_{3} \mathrm{O}_{4}$ nanocubes are incorporated onto the surfaces of graphene sheets. As can clearly be seen in Fig. 2(c), the rGO- $\mathrm{Co}_{3} \mathrm{O}_{4}$ nanocubes with $2 \mathrm{wt} \%$ of GO lacked sufficient graphene sheet surfaces to anchor the $\mathrm{Co}_{3} \mathrm{O}_{4}$ nanocubes, which resulted in a large number of $\mathrm{Co}_{3} \mathrm{O}_{4}$ nanocubes being exposed on the surface. When the GO content was increased to $12 \mathrm{wt} \%$ in the rGO- $\mathrm{Co}_{3} \mathrm{O}_{4}$ nanocubes (Fig. 2(d)) many of the $\mathrm{Co}_{3} \mathrm{O}_{4}$ nanocubes were sandwiched between the disorderly stacked graphene sheets, and few of the $\mathrm{Co}_{3} \mathrm{O}_{4}$ nanocubes were exposed on the surface. For comparison, the disorderly stacked graphene sheets and $\mathrm{Co}_{3} \mathrm{O}_{4}$ nanocubes prepared using the hydrothermal method are shown in Fig. 2(a and b).

TEM images of the $\mathrm{Co}_{3} \mathrm{O}_{4}$ nanocubes and $\mathrm{rGO}-\mathrm{Co}_{3} \mathrm{O}_{4}$ nanocubes are shown in Fig. 3. There is a clear distinction between the bare and graphene-supported $\mathrm{Co}_{3} \mathrm{O}_{4}$ nanocubes. Fig. 3(a) shows the $\mathrm{Co}_{3} \mathrm{O}_{4}$ nanocubes without any graphene sheets. As seen, the obtained materials had irregular shapes. It should be emphasized that the absence of graphene affected the $\mathrm{Co}_{3} \mathrm{O}_{4}$ nanocubes formation. The $\mathrm{Co}_{3} \mathrm{O}_{4}$ nanocubes 


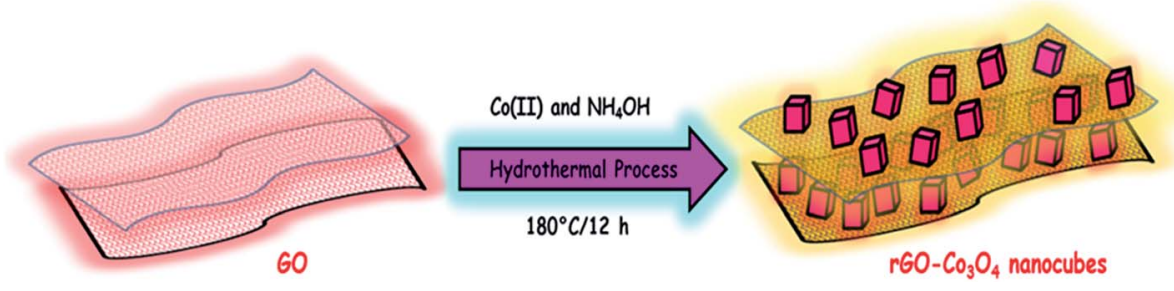

Fig. 1 Schematic representation for the preparation of $\mathrm{rGO}-\mathrm{CO}_{3} \mathrm{O}_{4}$ nanocubes.

incorporated graphene is shown in Fig. 3(b). It can be seen that the $\mathrm{Co}_{3} \mathrm{O}_{4}$ nanocubes are anchored on the transparent graphene sheet surfaces. This result clearly reveals that the graphene plays a role in the formation of $\mathrm{Co}_{3} \mathrm{O}_{4}$ nanocubes.

\section{X-ray diffraction analysis of $\mathrm{rGO}-\mathrm{Co}_{3} \mathrm{O}_{4}$ nanocubes}

The crystalline natures of the prepared $\mathrm{GO}, \mathrm{rGO}, \mathrm{Co}_{3} \mathrm{O}_{4}$ nanocubes, and $\mathrm{rGO}-\mathrm{Co}_{3} \mathrm{O}_{4}$ nanocubes were studied by recording the XRD patterns, and their results are shown in Fig. S1.† The GO (Fig. S1(a)†) shows a strong and sharp diffraction peak at the $2 \theta$ value of $10^{\circ}$ due to the (001) plane. ${ }^{20}$ After the hydrothermal process for GO, an intense sharp peak disappears at the $2 \theta$ value of $10^{\circ}$, and two new broad peaks appear at the $2 \theta$ values of $26.8^{\circ}$ and $42.7^{\circ}$, which can be attributed to the (002) and (100) planes for rGO, respectively (Fig. S1(b) $\dagger$ ). The two observed diffraction peaks originate from the disorderedly stacked graphene sheets, which confirms the successful reduction of GO into rGO. ${ }^{20,21}$ The $\mathrm{Co}_{3} \mathrm{O}_{4}$ nanocubes and $\mathrm{rGO}-\mathrm{Co}_{3} \mathrm{O}_{4}$ nanocubes (Fig. S1(c-d) $\dagger$ ) show a characteristic diffraction pattern at the $2 \theta$ values around $31.2^{\circ}, 36.8^{\circ}, 44.7^{\circ}, 55.5^{\circ}, 59.2^{\circ}$, and $65.1^{\circ}$, which were readily indexed to the respective (220), (311), (400), (422),
(511), and (440) planes of face centered cubic $\mathrm{Co}_{3} \mathrm{O}_{4}$ (JCPDS card no. 42-1467). ${ }^{21,22}$ For the rGO- $\mathrm{Co}_{3} \mathrm{O}_{4}$ nanocubes (Fig. $\mathrm{S} 1(\mathrm{~d}) \dagger$ ), the diffraction peak of rGO is undistinguishable, which clearly indicates that the face-to-face stacking of the rGO sheets is absent because of the formation of $\mathrm{Co}_{3} \mathrm{O}_{4}$ nanocubes on both sides of the rGO sheets. ${ }^{22}$

\section{Raman studies of rGO- $\mathrm{Co}_{3} \mathrm{O}_{4}$ nanocubes}

Raman analysis is more suitable tool and most commonly employed to differentiate the graphene (graphene oxide and reduced graphene oxide) from the very thin graphite sheets. It is known from the previous reports, ${ }^{23-26}$ the graphite sheets has inphase vibration of the highly ordered graphite lattice ( $\mathrm{G}$ band) at $1575 \mathrm{~cm}^{-1}$ and a very weak $\mathrm{D}$ band at $1355 \mathrm{~cm}^{-1}$ due to the disorder graphite edges. In contrast, the graphene oxide and reduced graphene oxide has well defined D and G band at 1355 and $1595 \mathrm{~cm}^{-1}$ in comparison with graphite..$^{23-26}$ The Raman spectra of the GO, rGO, $\mathrm{Co}_{3} \mathrm{O}_{4}$ nanocubes, and $\mathrm{rGO}-\mathrm{Co}_{3} \mathrm{O}_{4}$ nanocubes were recorded and are shown in Fig. 4. The Raman spectrum for GO shows D and G band peaks at 1355 and 1595 $\mathrm{cm}^{-1}$ due to the $\mathrm{sp}^{3}$ defects and in-plane vibrations of $\mathrm{sp}^{2}$ carbon

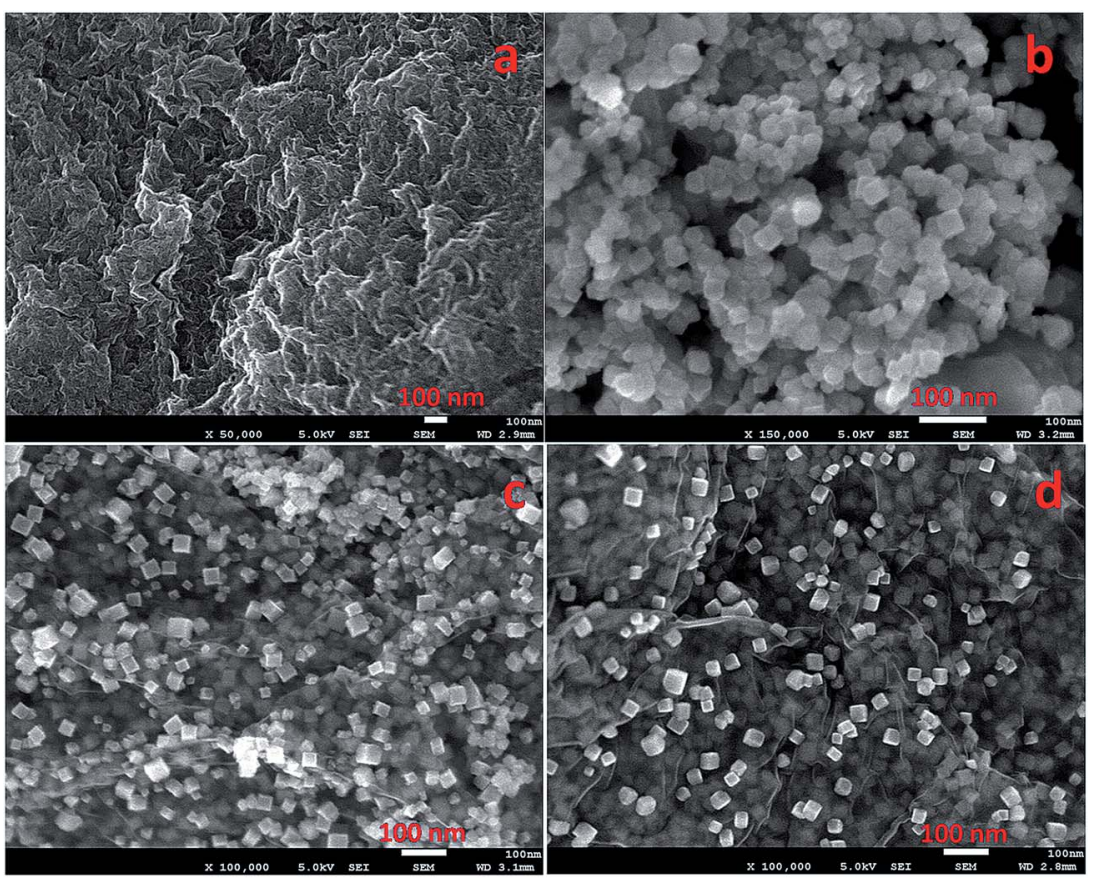

Fig. 2 FESEM images of (a) $\mathrm{rGO}$, (b) $\mathrm{Co}_{3} \mathrm{O}_{4}$ nanocubes, and (c and d) $\mathrm{rGO}-\mathrm{Co}_{3} \mathrm{O}_{4}$ nanocubes with 2 and 12 wt $\%$ of $\mathrm{GO}$. 


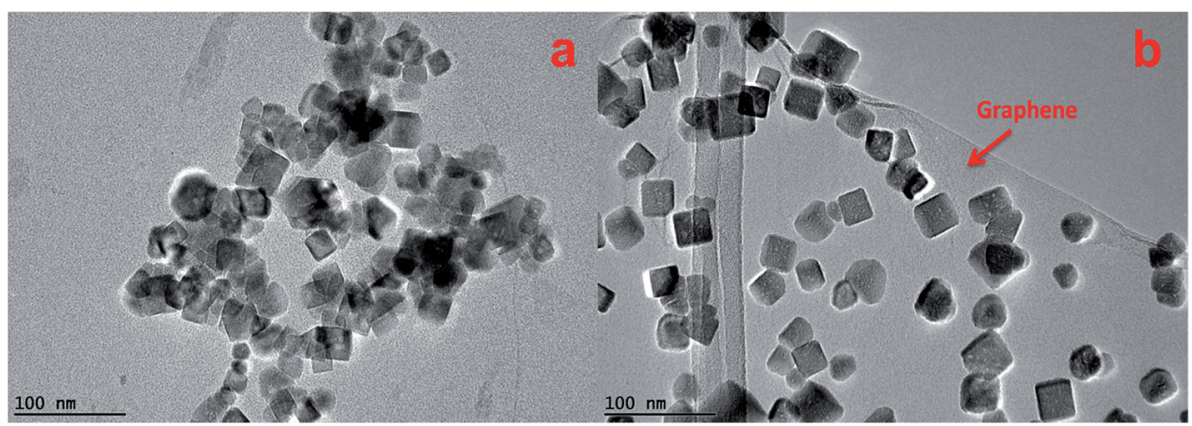

Fig. 3 TEM images of (a) $\mathrm{Co}_{3} \mathrm{O}_{4}$ nanocubes and (b) $\mathrm{rGO}-\mathrm{Co}_{3} \mathrm{O}_{4}$ nanocubes.

atoms, respectively. ${ }^{27,28} \mathrm{~A}$ small bump in Fig. 4(a and b) was observed related to the band 2D for GO $\left(2680 \mathrm{~cm}^{-1}\right)$ and rGO $\left(2694 \mathrm{~cm}^{-1}\right.$ ) respectively. This shows the multilayer GO and rGO, also a shift to higher wavelengths in the 2D band of rGO was observed after reduction from GO which indicates the restacking of graphene sheets due to the removal of functional group from GO which may prevent restacking of GO sheets after it was reduced. ${ }^{28}$ It was observed that $2 \mathrm{D}$ band of rGO in Fig. $4(\mathrm{~d})$ retain the same position as for GO showing no stacking of graphene layers. It may because of $\mathrm{Co}_{3} \mathrm{O}_{4}$ nanocubes behave like spacer in between the graphene sheets as confirmed by FESEM image. It was also demonstrated that $\mathrm{D}$ band remained unchanged, while the $\mathrm{G}$ band of rGO was shifted to $1610 \mathrm{~cm}^{-1}$ because of the "selfhealing" characteristics of the rGO, which recovers the hexagonal network of carbon atoms with defects. In addition $\mathrm{D} / \mathrm{G}$ band intensity ratio for rGO greater than that of GO suggesting decrease in $\mathrm{sp}^{2}$ domain of GO after reduction. ${ }^{27,29}$ This observation clearly indicates the successful transformation of GO to rGO (Fig. 4(a and b)). The Raman spectrum of the $\mathrm{rGO}-\mathrm{Co}_{3} \mathrm{O}_{4}$ nanocubes (Fig. 4(d)) shows four peaks at approximately 482, 525, 615, and $686 \mathrm{~cm}^{-1}$, which correspond to the $\mathrm{E}_{\mathrm{g}}, \mathrm{F}_{2 \mathrm{~g}}, \mathrm{~F}_{2 \mathrm{~g}}$, and $\mathrm{A}_{1 \mathrm{~g}}$ modes of $\mathrm{Co}_{3} \mathrm{O}_{4}$, along with the $\mathrm{D}$ and $\mathrm{G}$ bands for rGO. ${ }^{30-32}$

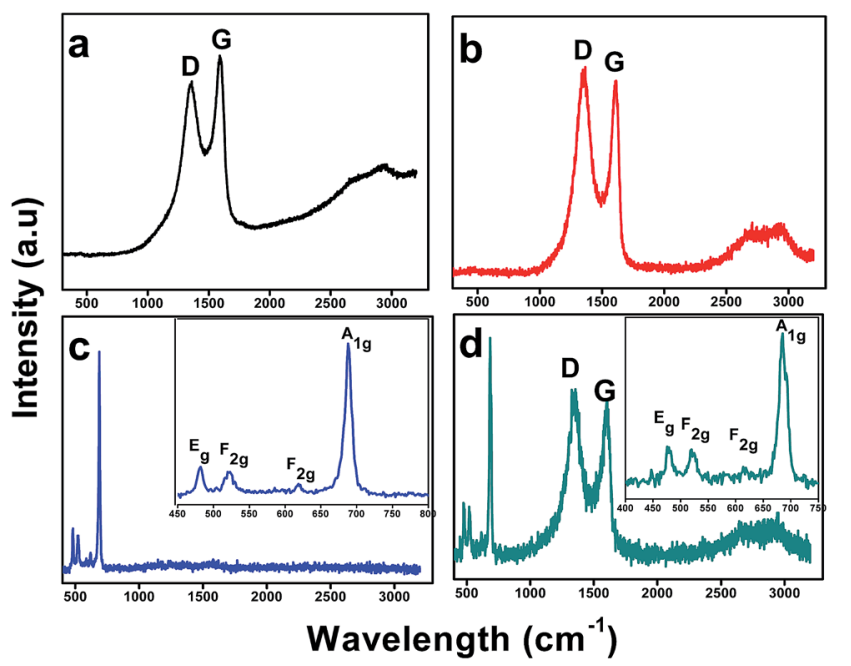

Fig. 4 Raman spectra obtained for the (a) $\mathrm{GO}$, (b) $\mathrm{rGO}$, (c) $\mathrm{Co}_{3} \mathrm{O}_{4}$ nanocubes, and (d) $\mathrm{rGO}-\mathrm{CO}_{3} \mathrm{O}_{4}$ nanocubes.
Electrochemical behavior of $\mathrm{rGO}-\mathrm{Co}_{3} \mathrm{O}_{4}$ nanocubes modified electrode

The rGO, $\mathrm{Co}_{3} \mathrm{O}_{4}$ nanocubes and $\mathrm{rGO}-\mathrm{Co}_{3} \mathrm{O}_{4}$ nanocubes modified electrodes were electrochemically characterized by recording the cyclic voltammograms in $0.1 \mathrm{M} \mathrm{KOH}$ at a scan rate of $50 \mathrm{mV} \mathrm{s}^{-1}$ and their results are shown in Fig. 5(A). All the cyclic voltammograms show a clear peak at $-0.2 \mathrm{~V}$ and a small peak at $-0.1 \mathrm{~V}$ due to the hydrogen adsorption/desorption processes in this potential region. The anodic peaks observed for $\mathrm{Co}_{3} \mathrm{O}_{4}$ nanocubes and $\mathrm{rGO}-\mathrm{Co}_{3} \mathrm{O}_{4}$ nanocubes modified electrodes around $50 \mathrm{mV}$ were due to the adsorption of oxygen containing species such as, $\mathrm{H}_{2} \mathrm{O}$ and $\mathrm{OH}^{-}, 33,34$ and another peak observed between $200-300 \mathrm{mV}$ was attributed to the formation of higher valence oxides or hydroxides of cobalt in the alkaline medium. ${ }^{34,35}$ The observed cathodic peaks at 70 and $480 \mathrm{mV}$ for the $\mathrm{Co}_{3} \mathrm{O}_{4}$ nanocubes and $\mathrm{rGO}-\mathrm{Co}_{3} \mathrm{O}_{4}$ nanocubes modified electrodes are related to the regeneration of $\mathrm{Co}$ (II) species. ${ }^{35}$ The overall electrochemical processes ${ }^{36-39}$ during the anodic and cathodic scans are given in eqn (1) and (2) below:

$$
\begin{gathered}
\mathrm{Co}_{3} \mathrm{O}_{4}+\mathrm{OH}^{-}+\mathrm{H}_{2} \mathrm{O} \leftrightarrow 3 \mathrm{CoOOH}+\mathrm{e}^{-} \\
\mathrm{CoOOH}+\mathrm{OH}^{-} \leftrightarrow \mathrm{CoO}_{2}+\mathrm{H}_{2} \mathrm{O}+\mathrm{e}^{-}
\end{gathered}
$$

The cyclic voltammograms for an $\mathrm{rGO}-\mathrm{Co}_{3} \mathrm{O}_{4}$ nanocubes modified electrode in the presence of $1 \mathrm{mM} \mathrm{K}_{3}\left[\mathrm{Fe}(\mathrm{CN})_{6}\right]$ in $0.1 \mathrm{M} \mathrm{KCl}$ at a scan rate of $50 \mathrm{mV} \mathrm{s}^{-1}$ shows a smaller peak potential separation $\left(\Delta E_{\mathrm{p}}\right)$ and larger peak current than those of a bare Pt electrode (Fig. 5(B)), indicating a rapid electron transfer and larger electroactive surface area for the rGO- $\mathrm{Co}_{3} \mathrm{O}_{4}$ nanocubes. After modification with $\mathrm{rGO}, \mathrm{Co}_{3} \mathrm{O}_{4}$ nanocubes, and $\mathrm{rGO}-\mathrm{Co}_{3} \mathrm{O}_{4}$ nanocubes, the $\Delta E_{\mathrm{p}}$ values decreased by 76,67 , and $60 \mathrm{mV}$, respectively, when compared to the bare $\mathrm{Pt}(80 \mathrm{mV})$, and the peak current increased on the order of $\mathrm{rGO}-\mathrm{Co}_{3} \mathrm{O}_{4}$ nanocubes $>\mathrm{Co}_{3} \mathrm{O}_{4}$ nanocubes $>$ rGO when compared to the bare Pt electrode (Fig. 5(B)). The noticeable increase in the anodic and cathodic peak current of the $\mathrm{rGO}-\mathrm{Co}_{3} \mathrm{O}_{4}$ nanocubes compared to the rGO confirmed the contribution of the $\mathrm{Co}_{3} \mathrm{O}_{4}$ nanocubes to an increase in the electroactive surface area and the promotion of electron transfer. Notably, the $\mathrm{rGO}-\mathrm{Co}_{3} \mathrm{O}_{4}$ nanocubes modified electrode showed a $\Delta E_{\mathrm{p}}$ value that was very similar to the ideal 

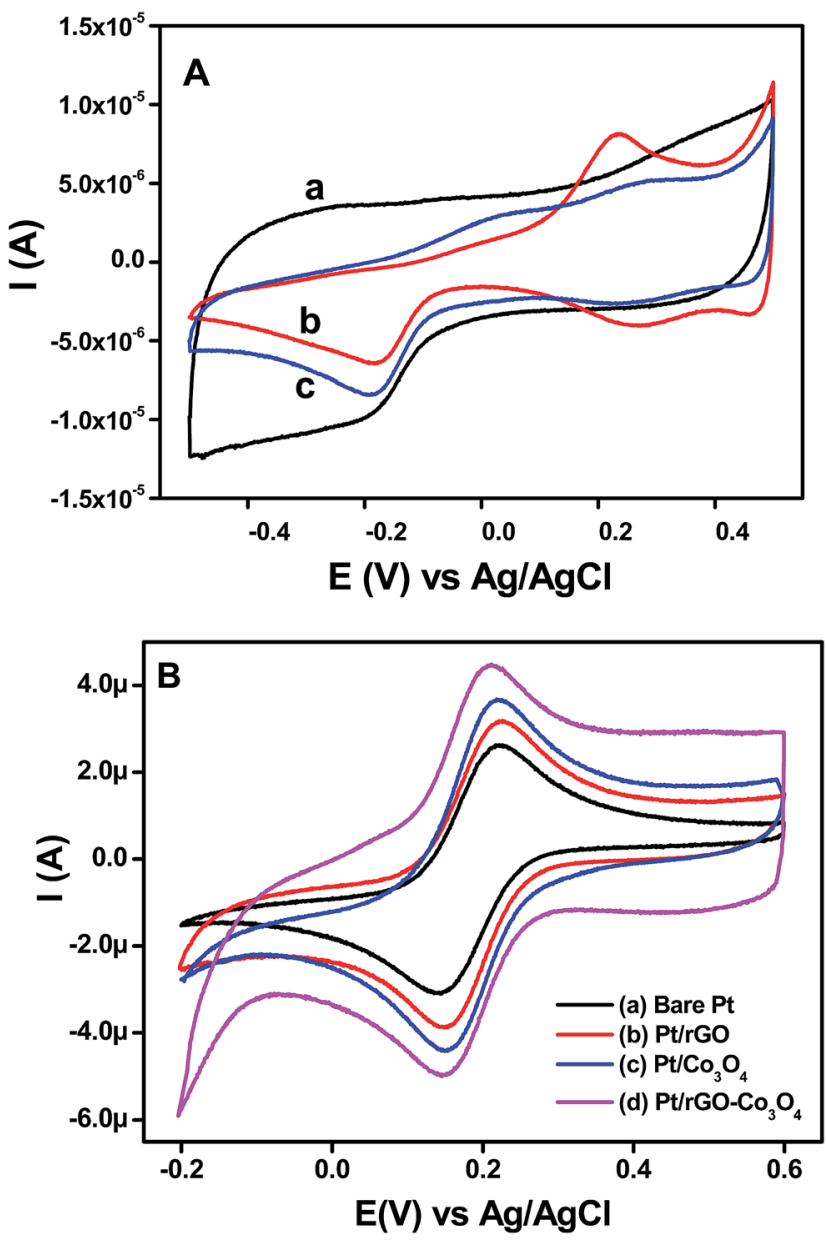

Fig. 5 (A) $\mathrm{CVs}$ obtained for the (a) $\mathrm{rGO}$, (b) $\mathrm{Co}_{3} \mathrm{O}_{4}$ nanocubes and (c) $\mathrm{rGO}-\mathrm{CO}_{3} \mathrm{O}_{4}$ nanocubes modified Pt electrodes in the presence of $0.1 \mathrm{M}$ $\mathrm{KOH}$ at scan rate of $50 \mathrm{mV} \mathrm{s}^{-1}$. (B) CVs recorded at (a) bare $\mathrm{Pt}$, (b) $\mathrm{rGO}$, (c) $\mathrm{CO}_{3} \mathrm{O}_{4}$ nanocubes and (d) $\mathrm{rGO}-\mathrm{CO}_{3} \mathrm{O}_{4}$ nanocubes modified electrodes for $1 \times 10^{-3} \mathrm{M} \mathrm{K}_{3}\left[\mathrm{Fe}(\mathrm{CN})_{6}\right]$ in $0.1 \mathrm{M} \mathrm{KCl}$ at a scan rate of $50 \mathrm{mV} \mathrm{s}^{-1}$.

kinetics $(59 \mathrm{mV})$ of a one-electron reversible process, suggesting the excellent conductivity and ideal reversibility of the redox reaction.

The scan rate was varied in the range of $10-500 \mathrm{mV} \mathrm{s}^{-1}$ for the $\mathrm{rGO}-\mathrm{Co}_{3} \mathrm{O}_{4}$ nanocubes modified electrode with $1 \times 10^{-3} \mathrm{M}$ of $\mathrm{K}_{3}\left[\mathrm{Fe}(\mathrm{CN})_{6}\right]$ in $0.1 \mathrm{M} \mathrm{KCl}$, and the results are shown in Fig. S2(A). $\dagger$ It can be seen that the redox peak current for the anodic and cathodic scan increased linearly with the increasing scan rate, and no obvious shift is observed for the anodic and cathodic peak potentials. This clearly suggests that the electrochemical redox reaction that occurs for the $\mathrm{rGO}-\mathrm{Co}_{3} \mathrm{O}_{4}$ nanocubes modified electrode is reversible. A plot of the anodic and cathodic peak current $v s$. square root of the scan rate is shown in Fig. S2(B), $\dagger$ which shows the linear relation for the rGO- $\mathrm{Co}_{3} \mathrm{O}_{4}$ nanocubes modified electrode $\left(R^{2}=0.9938\right.$ and $0.9942)$, indicating an adsorption controlled redox process. ${ }^{40}$

In order to investigate the electrochemical behavior of bare $\mathrm{Pt}, \mathrm{rGO}, \mathrm{Co}_{3} \mathrm{O}_{4}$ nanocubes and $\mathrm{rGO}-\mathrm{Co}_{3} \mathrm{O}_{4}$ nanocubes modified electrode, electrochemical impedance spectroscopic (EIS) analyses were performed by dipping the electrodes into a solution containing $1 \times 10^{-3} \mathrm{M} \mathrm{K}_{3}\left[\mathrm{Fe}(\mathrm{CN})_{6}\right]$ in $0.1 \mathrm{M} \mathrm{KCl}$ at a scanning frequency range of 0.01-120 $000 \mathrm{~Hz}$. The Nyquist plots for the bare $\mathrm{Pt}, \mathrm{rGO}, \mathrm{Co}_{3} \mathrm{O}_{4}$ nanocubes and $\mathrm{rGO}-\mathrm{Co}_{3} \mathrm{O}_{4}$ nanocubes modified electrodes show a line in the low-frequency region and an arc in the high frequency region (Fig. 6(A) and $\mathrm{S} 3 \dagger)$. The bare Pt electrode shows a large semicircle compared to the other modified electrodes, which is a result of the large charge-transfer resistance $\left(R_{\mathrm{ct}}\right)$ at the electrode/electrolyte interface due to the sluggish electron transfer kinetics. It can obviously be seen that $R_{\mathrm{ct}}$ decreased for the rGO, $\mathrm{Co}_{3} \mathrm{O}_{4}$ nanocubes and $\mathrm{rGO}-\mathrm{Co}_{3} \mathrm{O}_{4}$ nanocubes modified electrodes, which can be attributed to the presence of high conductive rGO sheets and catalytically active $\mathrm{Co}_{3} \mathrm{O}_{4}$ nanocubes on the electrode surface. Fig. 6(B) shows the Bode-phase plots of various modified electrodes in the frequency range of 0.1-10 $000 \mathrm{~Hz}$. A higher phase peak intensity can be seen at a frequency range of 100$1000 \mathrm{~Hz}$, which is attributed to the charge-transfer resistance of the modified electrode. ${ }^{41,42}$ Interestingly, the phase peaks in the Bode plots for the $\mathrm{rGO}, \mathrm{Co}_{3} \mathrm{O}_{4}$ nanocubes and $\mathrm{rGO}-\mathrm{Co}_{3} \mathrm{O}_{4}$ nanocubes modified electrode are shifted to a low frequency region of $0.1-100 \mathrm{~Hz}$ as a result of the high electron transfer behavior of the highly conductive rGO sheets and the catalytically active $\mathrm{Co}_{3} \mathrm{O}_{4}$ nanocubes based modified electrodes.
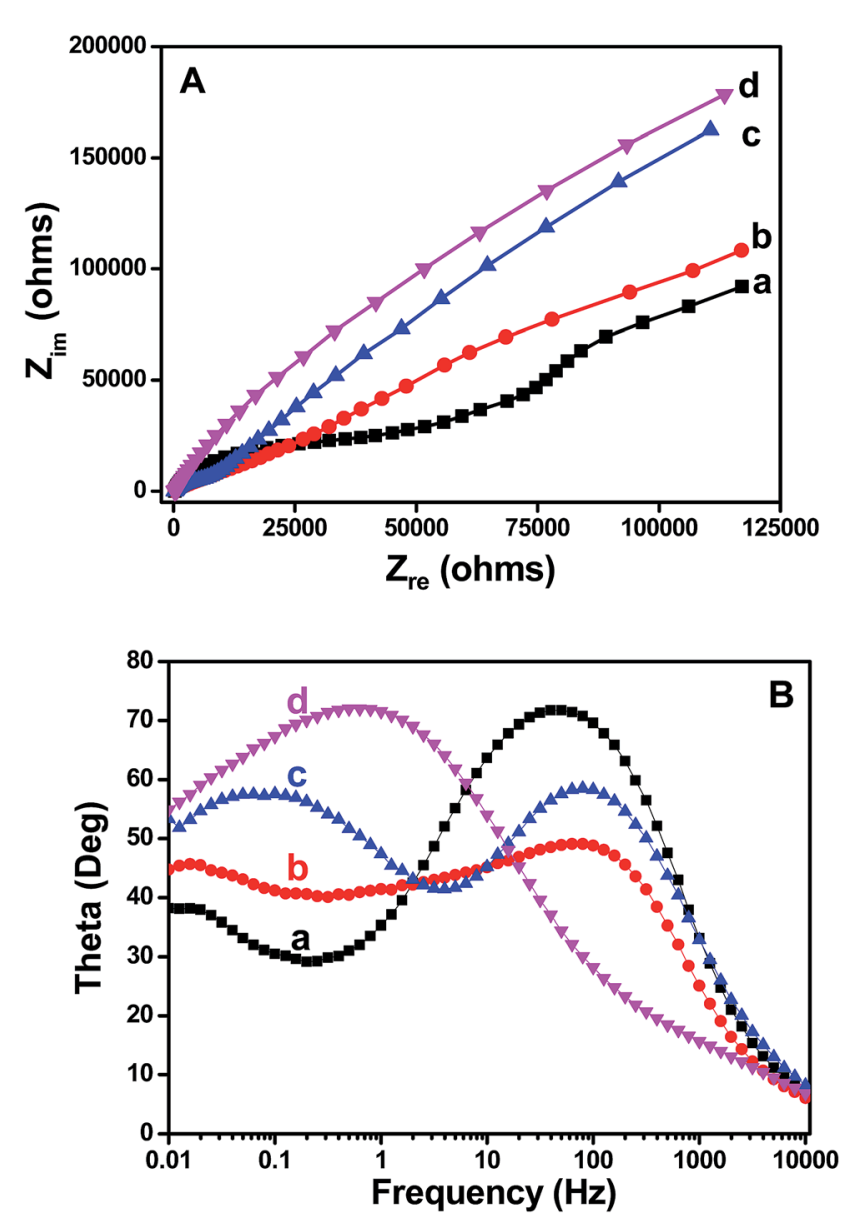

Fig. 6 (A) Nyquist plots and (B) Bode phase plots obtained for (a) bare $\mathrm{Pt}$, (b) $\mathrm{rGO}$, (c) $\mathrm{CO}_{3} \mathrm{O}_{4}$ nanocubes and (d) $\mathrm{rGO}-\mathrm{CO}_{3} \mathrm{O}_{4}$ nanocubes modified Pt electrodes for $1 \times 10^{-3} \mathrm{M} \mathrm{K}_{3}\left[\mathrm{Fe}(\mathrm{CN})_{6}\right]$ in $0.1 \mathrm{M} \mathrm{KCl}$. 
Electrocatalytic oxidation of methanol at $\mathrm{rGO}-\mathrm{Co}_{3} \mathrm{O}_{4}$ nanocubes modified electrode

The schematic representation of methanol oxidation at the $\mathrm{Pt} / \mathrm{rGO}-\mathrm{Co}_{3} \mathrm{O}_{4}$ modified electrode is shown in Fig. 7. During the electrooxidation of methanol, the anodic oxidation peak current is obtained due to the oxidation of freshly chemisorbed species coming from the adsorption of methanol and the formation of intermediate carbonaceous species in the forward scan and further it reacts with adsorbed $\mathrm{CO}$ on the electrode to produce $\mathrm{CO}_{2}, \mathrm{H}_{2} \mathrm{O}$, electron $\left(\mathrm{e}^{-}\right)$. In the reverse scan, the oxidation peak is primarily associated with removal/oxidation of carbonaceous species not completely oxidized in the forward scan, rather than caused by freshly chemisorbed species. In order to investigate the electrocatalytic activity of the prepared $\mathrm{rGO}-\mathrm{Co}_{3} \mathrm{O}_{4}$ nanocubes modified Pt electrode, a cyclic voltammogram was recorded in the presence of $0.1 \mathrm{M} \mathrm{CH}_{3} \mathrm{OH}$ and $0.1 \mathrm{M} \mathrm{KOH}$ at a scan rate of $50 \mathrm{mV} \mathrm{s}^{-1}$, and its results are shown in Fig. 8(d). For comparison purposes, cyclic voltammograms were also recorded for polycrystalline $\mathrm{Pt}, \mathrm{rGO}$ and $\mathrm{Co}_{3} \mathrm{O}_{4}$ nanocubes modified electrodes under the same conditions (Fig. 8(a-c)). Interestingly the $\mathrm{rGO}-\mathrm{Co}_{3} \mathrm{O}_{4}$ nanocubes modified electrode showed a higher electrocatalytic oxidation current density during forward $\left(358 \mu \mathrm{A} \mathrm{cm}^{-2}\right)$ and backward $\left(196 \mu \mathrm{A} \mathrm{cm}^{-2}\right)$ scans compared to the other modified electrodes (polycrystalline Pt, rGO, and $\mathrm{Co}_{3} \mathrm{O}_{4}$ nanocubes). The peak currents observed during the forward and reverse scans were due to the methanol oxidation and removal of the residual carbonaceous species formed in the forward scan, respectively. ${ }^{\mathbf{4 3 , 4 4}}$ The higher electrocatalytic activity of the $\mathrm{rGO}-\mathrm{Co}_{3} \mathrm{O}_{4}$ nanocubes modified electrode was mainly due to the combination of the cubic $\mathrm{Co}_{3} \mathrm{O}_{4}$ structure and highly conductive reduced graphene oxide (Fig. 2 and 4) and this catalytic activity is good in agreement with the FESEM and Raman results (Fig. 2 and 4 ). The enhanced structural features of $\mathrm{Co}_{3} \mathrm{O}_{4}$ nanocubes incorporated rGO resulted in the efficient electron transport to the active sites on the catalyst than the bare $\mathrm{Co}_{3} \mathrm{O}_{4}$ nanocubes. Hence, the FESEM images (Fig. 2) supported the fact that the high dispersion of $\mathrm{Co}_{3} \mathrm{O}_{4}$ nanocubes into the rGO matrix leads to significantly enhanced the electrocatalytic performance. Xiao et al. reported that the electrocatalytic activity was significantly influenced by the graphene when it was incorporated into different $\mathrm{Co}_{3} \mathrm{O}_{4}$ nanostructures. ${ }^{18}$

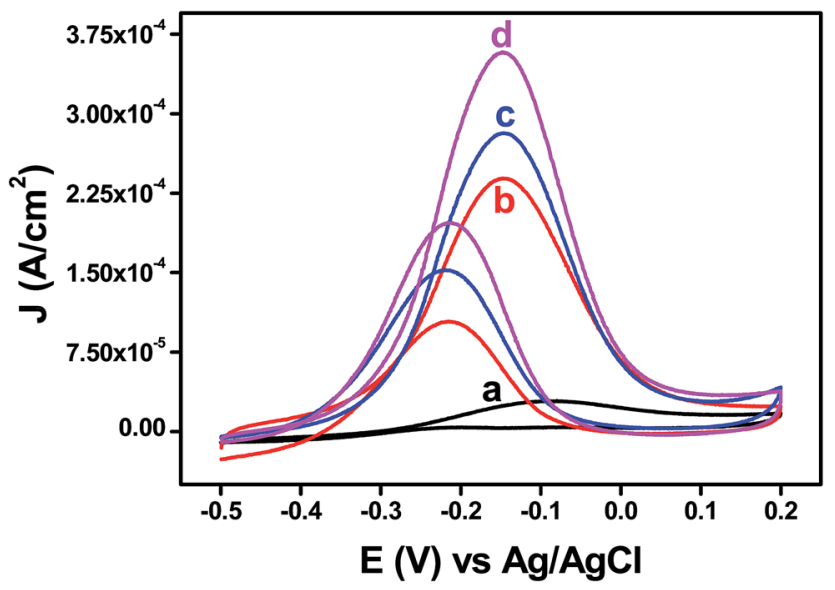

Fig. $8 \mathrm{CVs}$ obtained for the (a) bare $\mathrm{Pt}$, (b) $\mathrm{rGO}$, (c) $\mathrm{CO}_{3} \mathrm{O}_{4}$ nanocubes and (d) $\mathrm{rGO}-\mathrm{CO}_{3} \mathrm{O}_{4}$ nanocubes modified $\mathrm{Pt}$ electrodes in the presence of $0.1 \mathrm{M} \mathrm{CH}_{3} \mathrm{OH}$ and $0.1 \mathrm{M} \mathrm{KOH}$ at a scan rate of $50 \mathrm{mV} \mathrm{s}^{-1}$.

Optimization of rGO content in $\mathrm{rGO}-\mathrm{Co}_{3} \mathrm{O}_{4}$ nanocubes modified electrode for efficient methanol oxidation

Optimizing the weight percentage of the GO in the $\mathrm{rGO}-\mathrm{Co}_{3} \mathrm{O}_{4}$ nanocubes is very important to attain a high electrocatalytic performance toward methanol oxidation. In this regard, the $\mathrm{wt} \%$ of the GO content in the $\mathrm{rGO}-\mathrm{Co}_{3} \mathrm{O}_{4}$ nanocubes was varied and the obtained results are shown in Fig. S4(A). $\uparrow$ The observed results clearly suggest that the oxidation current density was increased during the forward and reverse scans with the increasing of the GO content until it reached a maximum of $2 \mathrm{wt} \%$ of GO in composite of $\mathrm{rGO}-\mathrm{Co}_{3} \mathrm{O}_{4}$. After this, a further increase in the GO content of the $\mathrm{rGO}-\mathrm{Co}_{3} \mathrm{O}_{4}$ nanocubes led to a decrease in the current density during the forward and reverse scans (Fig. S4(A) $\dagger$ ). The observed current densities for methanol oxidation during the forward and reverse scan for $\mathrm{rGO}-\mathrm{Co}_{3} \mathrm{O}_{4}$ nanocubes with different GO contents are summarized in Fig. S4(B). $\uparrow$ The decrease in the current density with increasing GO content, which was due to the decrease in the anodic peak current that resulted from the restacking of the graphene nanosheets, substantially decreased the active catalytic sites on the electrocatalysts. ${ }^{45,46}$
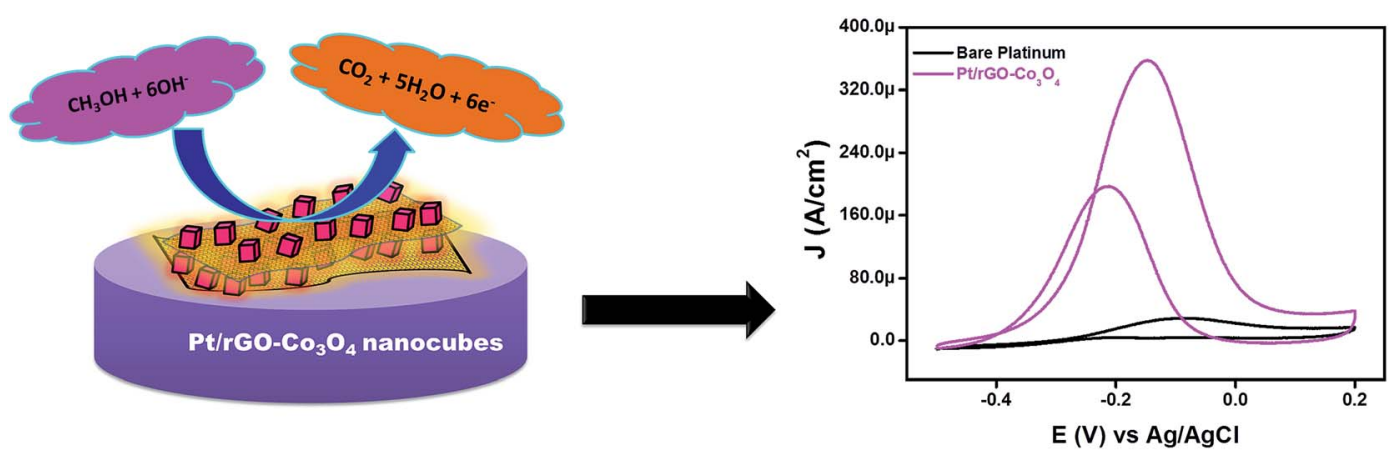

Fig. 7 Schematic mechanism for the electrocatalytic oxidation of methanol at $\mathrm{Pt} / \mathrm{rGO}-\mathrm{Co}_{3} \mathrm{O}_{4}$ modified electrode. 
Influence of scan rate and methanol concentration on electrocatalytic activity of $\mathrm{rGO}-\mathrm{Co}_{3} \mathrm{O}_{4}$ nanocubes modified electrode

The effect of the scan rate on the electrocatalytic oxidation of methanol was investigated for the $\mathrm{rGO}-\mathrm{Co}_{3} \mathrm{O}_{4}$ nanocubes modified electrode in the presence of $0.1 \mathrm{M} \mathrm{CH}_{3} \mathrm{OH}$ and $0.1 \mathrm{M}$ $\mathrm{KOH}$ at different scan rates in the range of $10-200 \mathrm{mV} \mathrm{s}^{-1}$, and the results are shown in Fig. 9(A). It can be seen that the oxidation peak current density increased with increasing scan rate. The observed anodic peak current density is plotted against the scan rate for the $\mathrm{rGO}-\mathrm{Co}_{3} \mathrm{O}_{4}$ nanocubes modified electrode and is shown in the inset of Fig. 9(A). An increase in the scan rate likely enhanced the electron movement. The $\mathrm{rGO}-\mathrm{Co}_{3} \mathrm{O}_{4}$ nanocubes modified electrode showed a linear relationship between the anodic peak current density obtained from the forward scans and the square root of the scan rate toward methanol oxidation. This suggests that the oxidation of methanol at the $\mathrm{rGO}-\mathrm{Co}_{3} \mathrm{O}_{4}$ nanocubes modified electrode is a diffusion-controlled process.
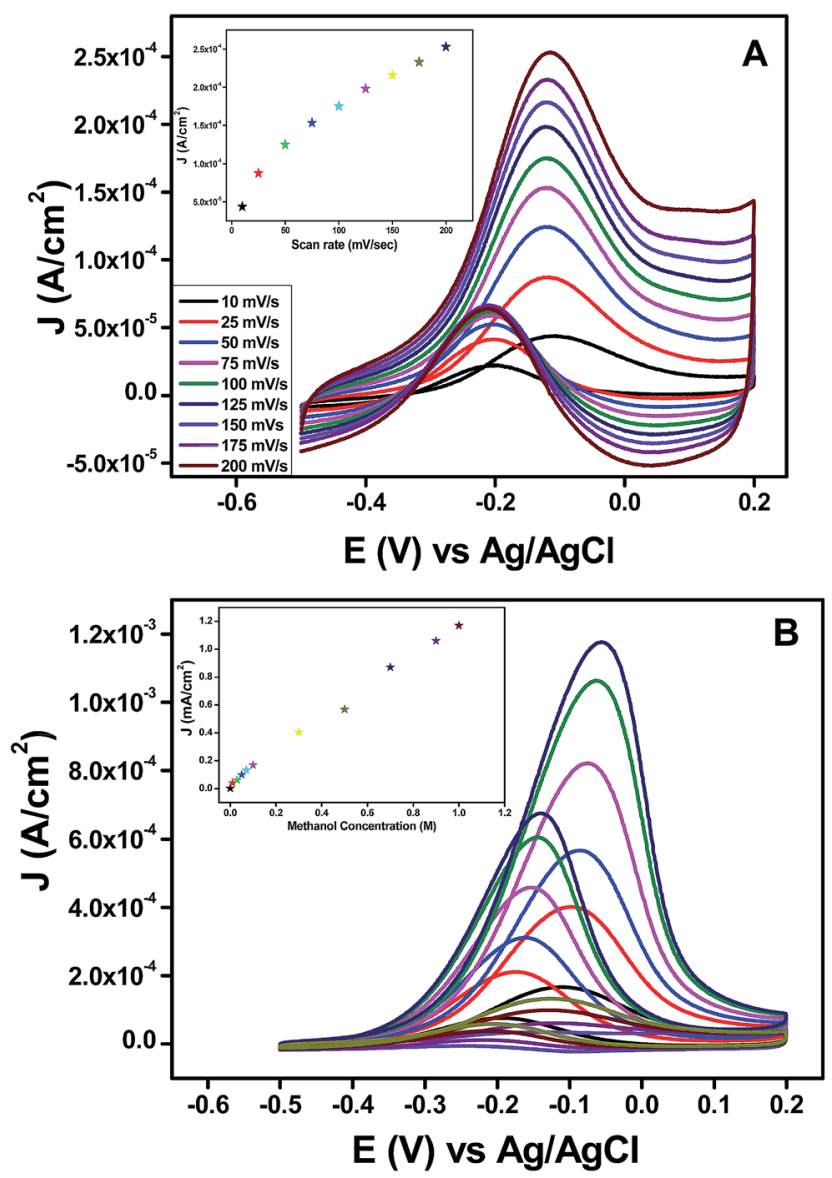

Fig. 9 (A) $\mathrm{CV}$ recorded for $\mathrm{rGO}-\mathrm{CO}_{3} \mathrm{O}_{4}$ nanocubes modified $\mathrm{Pt}$ electrode in presence of $0.1 \mathrm{M} \mathrm{CH}_{3} \mathrm{OH}$ and $0.1 \mathrm{M} \mathrm{KOH}$ at different scan rates in range of $10-200 \mathrm{mV} \mathrm{s}^{-1}$. (Inset) Plot of scan rate versus anodic peak current density obtained from the $\mathrm{CV}$ measurements. (B) $\mathrm{CV}$ recorded for $\mathrm{rGO}-\mathrm{CO}_{3} \mathrm{O}_{4}$ nanocubes modified electrode at scan rate $50 \mathrm{mV} \mathrm{s}^{-1}$ in presence of $0.1 \mathrm{M} \mathrm{KOH}$ and various concentrations of $\mathrm{CH}_{3} \mathrm{OH}$. (Inset) Plot of methanol concentration versus anodic peak current density for $\mathrm{rGO}-\mathrm{CO}_{3} \mathrm{O}_{4}$ nanocubes modified Pt electrode.
The methanol concentration is a crucial factor in the practical application of direct methanol fuel cells. The influence of the methanol concentration was studied by varying the methanol content in an $\mathrm{rGO}-\mathrm{Co}_{3} \mathrm{O}_{4}$ nanocubes modified electrode at a scan rate of $50 \mathrm{mV} \mathrm{s}^{-1}$ in the presence of $0.1 \mathrm{M} \mathrm{KOH}$ and the results are shown in Fig. 9(B). It can be observed that the anodic peak current density increases and the anodic peak potential have a slightly positive shift with an increase in the methanol concentration. The positive shift in the anodic peak potential with increasing methanol concentration is due to the saturation of active sites at the surface of the $\mathrm{rGO}-\mathrm{Co}_{3} \mathrm{O}_{4}$ nanocubes modified electrode.

\section{Reversibility and stability of the $\mathrm{rGO}-\mathrm{Co}_{3} \mathrm{O}_{4}$ nanocubes modified electrode towards methanol oxidation}

The reliability of the Pt electrode modified with the $\mathrm{rGO}-\mathrm{Co}_{3} \mathrm{O}_{4}$ nanocubes towards the electrocatalytic oxidation of methanol was investigated by repeating the CV measurements continually up to 100 cycles. Fig. 10(A) shows the CV curves for the proposed
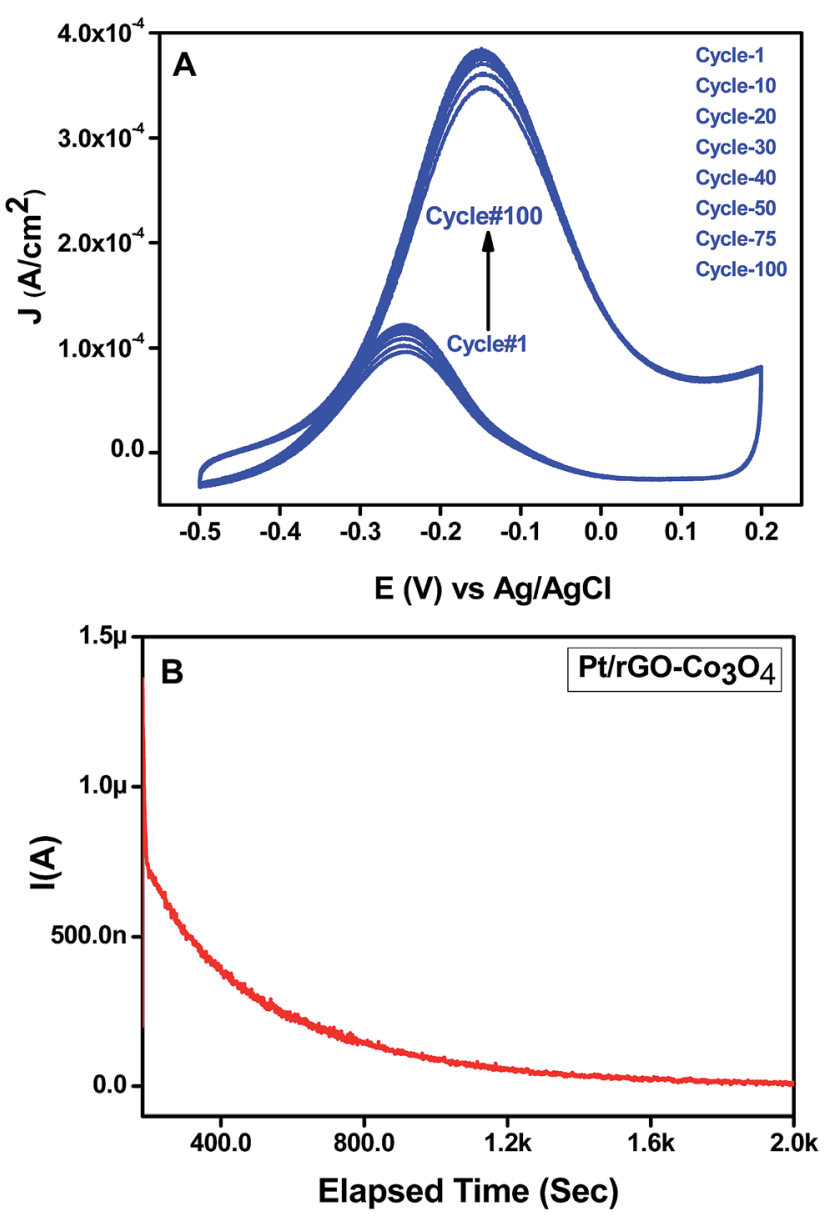

Fig. 10 (A) Cyclic voltammograms obtained for the $\mathrm{rGO}-\mathrm{Co}_{3} \mathrm{O}_{4}$ nanocubes modified Pt electrode in the presence of $0.1 \mathrm{M} \mathrm{CH}_{3} \mathrm{OH}$ and $0.1 \mathrm{M} \mathrm{KOH}$ at a scan rate of $50 \mathrm{mV} \mathrm{s}^{-1}$ with 1 to 100 cycles. (B) Chronoamperometric curve obtained for the $\mathrm{Pt} / \mathrm{rGO}-\mathrm{CO}_{3} \mathrm{O}_{4}$ modified electrode in the presence of $1 \mu \mathrm{M} \mathrm{CH}_{3} \mathrm{OH}$ and $0.1 \mathrm{M} \mathrm{KOH}$ at a scan rate of $50 \mathrm{mV} \mathrm{s}^{-1}$ at a fixed potential of $-150 \mathrm{mV}$ vs. Ag/AgCl. 
$\mathrm{Pt} / \mathrm{rGO}-\mathrm{Co}_{3} \mathrm{O}_{4}$ modified electrode in $0.1 \mathrm{M} \mathrm{KOH}$ and $0.1 \mathrm{M}$ $\mathrm{CH}_{3} \mathrm{OH}$. It can be clearly seen that the $\mathrm{CV}$ curves are stable and the current density at $-150 \mathrm{mV}$ (vs. $\mathrm{Ag} / \mathrm{AgCl}$ ) shows $108 \%$ retention (increased from 350 to $380 \mu \mathrm{A} \mathrm{cm} \mathrm{cm}^{-2}$ ) after 100 cycles. Thus, the proposed $\mathrm{Pt} / \mathrm{rGO}-\mathrm{Co}_{3} \mathrm{O}_{4}$ modified electrode shows good sensitivity and better stability towards the electrocatalytic oxidation of methanol.

The electrocatalytic stability of the $\mathrm{Pt} / \mathrm{rGO}-\mathrm{Co}_{3} \mathrm{O}_{4}$ modified electrode was studied using chronoamperometry. Fig. 10(B) showed the chronoamperometric curve of $1 \mathrm{mM} \mathrm{CH} \mathrm{CH}_{3} \mathrm{OH}$ in $0.1 \mathrm{KOH}$ for the $\mathrm{Pt} / \mathrm{rGO}-\mathrm{Co}_{3} \mathrm{O}_{4}$ modified electrode at an applied potential of $-150 \mathrm{mV}$ and the electrode shows the rapid decrease in the potentiostatic current at the initial stage during the oxidation of methanol due to the formation of intermediate species, such as $\mathrm{CO}_{\mathrm{ads}}$ and $\mathrm{CHO}_{\mathrm{ads}}$ etc. ${ }^{\mathbf{4 7 , 4 8}}$ Then, the current was gradually decayed and achieved the pseudo-steady state. Similar observation also reported to illustrate the stability of the modified electrode for the electrocatalytic oxidation of methanol with the Pt/graphene, ${ }^{48} \mathrm{Pt} /$ Vulcan, ${ }^{48} \mathrm{Pt} / \mathrm{C}-\mathrm{MoC}-\mathrm{Gl} .{ }^{49}$

\section{Conclusions}

$\mathrm{Co}_{3} \mathrm{O}_{4}$ nanocubes incorporating reduced graphene oxide were successfully synthesized using a simple hydrothermal method. The as-prepared $\mathrm{rGO}-\mathrm{Co}_{3} \mathrm{O}_{4}$ nanocubes combined the unique properties of graphene with the effects of $\mathrm{Co}_{3} \mathrm{O}_{4}$ nanocubes and showed a superior electrocatalytic activity and high poisoning tolerance for methanol electro-oxidation compared with bare $\mathrm{Pt}, \mathrm{rGO}$ and $\mathrm{Co}_{3} \mathrm{O}_{4}$ nanocube modified electrodes. In particular, the best electrocatalytic activity for the $\mathrm{rGO}-\mathrm{Co}_{3} \mathrm{O}_{4}$ nanocube modified electrode in an alkaline environment could be achieved with an optimized GO content of $2 \mathrm{wt} \%$, and it showed an anodic peak current density of $362 \mu \mathrm{A} \mathrm{cm} \mathrm{cm}^{-2}$ during the forward scan. Further, the modified electrode showed good reversibility with the retention of $108 \%$ and stability towards methanol oxidation. Considering the low-cost, facile, and controllable method for the preparation of $\mathrm{rGO}-\mathrm{Co}_{3} \mathrm{O}_{4}$ nanocubes and the improved electrocatalytic activity toward methanol oxidation, this direct strategy can applied to the development of metal oxide-graphene composites as new electrode materials for high performance direct methanol fuel cells.

\section{Acknowledgements}

This work was financially supported by a University of Malaya Research Grant UMRG Programme (RP007C-13AFR) Science Fund from the Ministry of Science, Technology and Innovation (06-01-04-SF1513); and a High Impact Research Grant from the Ministry of Higher Education of Malaysia (UM.C/625/1/HIR/ $\mathrm{MOHE} / \mathrm{SC} / 21)$.

\section{References}

1 N. Armaroli and V. Balzani, Angew. Chem., Int. Ed., 2007, 46, 52. 2 I. Dincer, Renewable Sustainable Energy Rev., 2000, 4, 157.

3 H.-J. Choia, S.-M. Junga, J.-M. Seoa, D. W. Chang, L. Daic and J.-B. Baeka, Nano Energy, 2012, 1, 534.
4 X. Li and A. Faghri, J. Power Sources, 2013, 226, 223.

5 W. Zheng, A. Suominen and A. Tuominen, Energy Procedia, 2012, 28, 78.

6 X. Zhao, M. Yin, L. Ma, L. Liang, C. Liu, J. Liao, T. Luc and W. Xing, Energy Environ. Sci., 2011, 4, 2736.

7 V. Chabot, D. Higgins, A. Yu, X. Xiao, Z. Chena and J. Zhang, Energy Environ. Sci., 2014, 7, 1564.

8 H. Huang and X. Wang, J. Mater. Chem. A, 2014, 2, 6266.

9 X. Zhou, J. Qiao, L. Yang and J. Zhang, Adv. Energy Mater., 2014, 4, 1301523.

10 S. H. Hur and J. N. Park, Asia-Pac. J. Chem. Eng., 2013, 8, 218. 11 N. Mahmood, C. Zhang, H. Yin and Y. Hou, J. Mater. Chem. A, 2014, 2, 15.

12 A. Li, J. Liu and S. Feng, Sci. Adv. Mater., 2014, 6, 209.

13 S. Guo and S. Dong, Chem. Soc. Rev., 2011, 40, 2644.

14 C. Zhu and S. Dong, Nanoscale, 2013, 5, 10765.

15 M. Liu, R. Zhang and W. Chen, Chem. Rev., 2014, 114, 5117. 16 F. Jiao and H. Frei, Energy Environ. Sci., 2010, 3, 1018.

17 Z.-S. Wua, G. Zhoua, L.-C. Yina, W. Rena, F. Lia and H.-M. Chenga, Nano Energy, 2012, 1, 107.

18 J. Xiao, Q. Kuang, S. Yang, F. Xiao, S. Wang and L. Guo, Sci. Rep., 2013, 3, 2300.

19 H. N. Ming, H. N. Lim, C. H. Chia, M. A. Yarmo and M. R. Muhamad, Int. J. Nanomed., 2011, 6, 3443.

20 G. Wang, J. Yang, J. Park, X. Gou, B. Wang, H. Liu and J. Yao, J. Phys. Chem. C, 2008, 112, 8192.

21 Z.-S. Wu, W. Ren, L. Wen, L. Gao, J. Zhao, Z. Chen, G. Zhou, F. Li and H.-M. Cheng, ACS Nano, 2010, 4, 3187.

22 Z. Songa, Y. Zhangc, W. Liu, S. Zhang, G. Liuc, H. Chena and J. Qiu, Electrochim. Acta, 2013, 112, 120.

23 A. C. Ferrari, Solid State Commun., 2007, 143, 47-57.

24 N. K. Konstantin, O. Bulent, C. S. Hannes, K. P. Robert, A. A. Ilhan and C. Roberto, Nano Lett., 2008, 8, 36-41.

25 J. K. Hyo, S.-M. Lee, Y.-S. Oh, Y.-H. Yang, Y. S. Lim, D. H. Yoon, C. Lee, J.-Y. Kim and R. S. Ruoff, Sci. Rep., 2014, 4, 5176.

26 R. Tuinstra and J. L. Koenig, J. Chem. Phys., 1970, 53, 11261130.

27 S. Stankovich, D. A. Dikin, R. D. Piner, K. A. Kohlhaas, A. Kleinhammes, Y. Jia, Y. Wu, S. T. Nguyen and R. S. Ruoff, Carbon, 2007, 45, 1558.

28 S. Thakur and N. Karak, Carbon, 2012, 50, 5331.

29 Q. Zheng, B. Zhang, X. Lin, X. Shen, N. Yousefi, Z.-D. Huang,

Z. Li and J.-K. Kim, J. Mater. Chem., 2012, 22, 25072.

30 H. Kim, D.-H. Seo, S.-W. Kim, J. Kim and K. Kang, Carbon, 2011, 49, 326.

31 J. Jiang and L. Li, Mater. Lett., 2007, 61, 4894.

32 H.-C. Liu and S.-K. Yen, J. Power Sources, 2007, 166, 478-484.

33 S. Bruckenstein and M. Shay,J. Electroanal. Chem., 1985, 188, 131-136.

34 M. Jafarian, M. G. Mahjani, H. Heli, F. Gobal, H. Khajehsharifi and M. H. Hamedi, Electrochim. Acta, 2003, 48, 3423.

35 I. G. Casella, J. Electroanal. Chem., 2002, 520, 119.

36 S. Park and S. Kim, Electrochim. Acta, 2013, 89, 516.

37 X. Wang, S. Liu, H. Wang, F. Tu, D. Fang and Y. Li, J. Solid State Electrochem., 2012, 16, 3593. 
38 F. Svegl, B. Orel, M. Hutchins and K. Kalcher, J. Electrochem. Soc., 1996, 143, 1532.

39 C. Lin, J. A. Ritter and B. N. Popov, J. Electrochem. Soc., 1998, 145, 4097.

40 Z. Zhuang, J. Li, R. Xu and D. Xiao, Int. J. Electrochem. Sci., 2011, 6, 2149.

41 H. Choi, C. Nahm, J. Kim, J. Moon, S. Nam, D.-R. Jung and B. Park, Curr. Appl. Phys., 2012, 12, 737.

42 M. Gao, C. K. N. Peh, W. L. Ong and G. W. Ho, RSC Adv., 2013, 3, 13169.

43 S. Sharma, A. Ganguly, P. Papakonstantinou, X. Miao, M. Li, J. L. Hutchison, M. Delichatsios and S. Ukleja, J. Phys. Chem. C, 2010, 114, 19459 .
44 S. Xiao, F. Xiao, Y. Hu, S. Yuan, S. Wang, L. Qian and Y. Liu, Sci. Rep., 2014, 4, 4370.

45 Y. Jiang, Y. Lu, F. Li, T. Wu, L. Niu and W. Chen, Electrochem. Commun., 2012, 19, 21.

46 A. Sudarvizhi, Z. A. Siddiqha and K. Pandian, J. Chem. Appl. Biochem., 2014, 1, 101.

47 A. Kabbabi, R. Faure, R. Durand, B. Beden, F. Hahn, J.-M. Leger and C. Lamy, J. Electroanal. Chem., 1998, 444, 41.

48 Y. Li, L. Tang and J. Li, Electrochem. Commun., 2009, 11, 846.

49 Z. Yan, G. He, P.-K. Shen, Z. Luo, J. Xie and M. Chen, J. Mater. Chem. A, 2014, 2, 4014. 